\title{
Hyperemesis Gravidarum: A Benign Condition of Pregnancy or a Challenging Metabolic Disorder?
}

\author{
Matilda Florentin ${ }^{1}$, Ioannis Parthymos ${ }^{1}$, Aris P Agouridis² ${ }^{\text {, George Liamis }}{ }^{1}$ \\ ${ }^{1}$ Department of Internal Medicine, School of Medicine, University of Ioannina, loannina, Greece \\ ${ }^{2}$ School of Medicine, European University Cyprus, Nicosia, Cyprus
}

Received: 29/08/2020

Accepted: $15 / 09 / 2020$

Published: $16 / 10 / 2020$ How to cite this article: Florentin M. Parthymos I, Agouridis AP, Liamis G. Hyperemesis gravidarum: a benign condition of pregnancy or a challenging
metabolic disorder? EJCRIM 2020;7: doi:10.12890/2020_001979.

Conflicts of Interests: The Authors declare that there are no competing interests.

This article is licensed under a Commons Attribution Non-Commercial 4.0 License

\section{ABSTRACT}

Hyperemesis gravidarum (HG) is a complication mainly of the first trimester of pregnancy, which sometimes leads to metabolic disorders such as hypovolemia and acute kidney injury (AKI). Herein, we present the case of a 25-year-old woman at week 10 of gestation who exhibited a constellation ofsevere abnormalities, namely AKI (serum creatinine $6.15 \mathrm{mg} / \mathrm{dl}$ ), transaminasemia (serum aminotransferases $>1,000 \mathrm{IU} / \mathrm{I}$ ), alkalemia (arterial pH7.667), hyponatremia (serum sodium $117 \mathrm{mEq} / \mathrm{l}$ ), hypochloremia (serum chloride $54 \mathrm{mEq} / \mathrm{l}$ ), hypokalemia (serum potassium $2.2 \mathrm{mEq} / \mathrm{l}$ ) and hyperuricemia (serum uric acid $20 \mathrm{mg} / \mathrm{dl}$ ). Despite a thorough work-up, no other disorder was found apart from HG. All symptoms and metabolic abnormalities resolved with targeted administration of intravenous fluids. The differential diagnosis of these disorders and therapeutic challenges are discussed.

\section{LEARNING POINTS}

- Hyperemesis gravidarum is a severe form of vomiting during pregnancy that typically occurs in the first trimester.

- It may lead to severe metabolic abnormalities including acute kidney injury (AKI), and electrolyte and acid-base disturbances.

- Early detection, thorough diagnostic evaluation and prompt management with fluid resuscitation are essential for the well-being of both the mother and the fetus.

\section{KEYWORDS}

Acute kidney injury, alkalemia, hepatitis, hyperemesis gravidarum, hypokalemia, hyponatremia, hypovolemia

\section{INTRODUCTION}

Hyperemesis gravidarum (HG) is a severe form of nausea and vomiting affecting $0.3-3 \%$ of pregnancies ${ }^{[1]}$. The most common criteria for its diagnosis include dehydration due to vomiting, ketonuria caused by acute starvation, electrolyte and acid-base disturbances and at least $5 \%$ loss of pre-pregnancy weight ${ }^{[2]}$. Herein, we present a case of HG with significant acute kidney injury (AKI), alkalemia, extreme hyponatremia, hypochloremia, hypokalemia and hyperuricemia, along with severe hepatic impairment.

\section{CASE DESCRIPTION}

A 25-year-old woman at week 10 of gestation was brought to the emergency department with altered mental status. Her relatives reported nausea and vomiting since the beginning of pregnancy, which had not caused health issues so far. They did not report fever, diarrhoea, shortness of breath, pain or other symptoms and denied drug or alcohol use. At admission, the patient opened her eyes, localized to pain 
and was confused (Glasgow Coma Scale 11/15). Her pupils were equal in size and responded to light. Her blood pressure and heart rate were 105/65 mmHg and 110 beats/min, respectively, in the supine position and 82/55 $\mathrm{mmHg}$ and 120 beats/min, respectively, in the sitting position. Respiration was 22 breaths/min and her temperature was $36.4^{\circ} \mathrm{C}$. The rest of the physical examination was significant for dry skin and mucosa and jaundice. There was no organomegaly, lymphadenopathy, skin rash or petechiae. No cardiac murmurs were heard, the lungs were clear to auscultation and there was no tenderness at the abdomen. Arterial blood gases demonstrated a pH of 7.667 with $\mathrm{PCO}_{2} 38$ $\mathrm{mmHg}$ and $\mathrm{HCO}^{3}-44.8 \mathrm{mEq} / \mathrm{I}$. The laboratory exams demonstrated AKI with pre-renal azotemia, several electrolyte disorders and hepatic alterations (Table 1). The urinalysis was significant for increased specific gravity (1030) and the presence of ketones. The electrocardiogram revealed $U$ waves. The gynaecologists asked for consultation with other clinicians due to multiple metabolic abnormalities.

\begin{tabular}{|c|c|c|c|}
\hline & Values at admission & Values at discharge & Normal range \\
\hline \multicolumn{4}{|c|}{ Laboratory parameters* } \\
\hline $\mathrm{Ht}(\%)$ & 38.9 & 36.2 & $36-46$ \\
\hline$H b(g / d l)$ & 15 & 12.2 & $11.2-16$ \\
\hline WBC (/mm3) & 17,920 & 11,230 & $4,000-11,000$ \\
\hline PLT (/mm3) & 258,000 & 257,000 & $150,000-450,000$ \\
\hline Cre/Urea (mg/dl) & $6.15 / 160$ & $1.0 / 34$ & $0.6-1.2 / 11-54$ \\
\hline $\mathrm{Na}+(\mathrm{mEq} / \mathrm{l})$ & 117 & 138 & $135-146$ \\
\hline$K+(m E q / l)$ & 2.20 & 3.9 & $3.5-5.3$ \\
\hline$U A(m g / d l)$ & 20 & 5.5 & $3.4-6.5$ \\
\hline AST/ALT (IU/I) & $1,203 / 1,695$ & $120 / 273$ & $10-35 / 10-35$ \\
\hline YGT/ALP (IU/I) & $83 / 145$ & $52 / 126$ & $10-52 / 30-125$ \\
\hline TBIL/DBIL (mg/dl) & $5.3 / 3.07$ & $1.7 / 0.5$ & $0.1-1 / 0.01-0.2$ \\
\hline \multicolumn{4}{|c|}{ Urinalysis } \\
\hline Ketones & ++ & - & - \\
\hline \multicolumn{4}{|c|}{ Arterial blood gases } \\
\hline$p H$ & 7.667 & 7.39 & $7.35-7.45$ \\
\hline $\mathrm{pCO} 2(\mathrm{mmHg})$ & 38 & 41 & $35-42$ \\
\hline $\mathrm{pO} 2(\mathrm{mmHg})$ & 71 & 75 & $80-100$ \\
\hline $\mathrm{HCO} 3-(\mathrm{mmol} / \mathrm{l})$ & 44.8 & 24 & $22-26$ \\
\hline Anion gap & 18.2 & 12 & $6-12$ \\
\hline \multicolumn{4}{|c|}{ Specific laboratory exams* } \\
\hline $\begin{array}{l}\text { ANA, AMA, ASMA, ANCA, } \\
\text { anti-LKM, anti-SLA antibodies }\end{array}$ & $(-)$ & & \\
\hline
\end{tabular}

Table 1. Laboratory findings at admission and at discharge

*Serological tests for viral hepatitis (A, B, C, D E), as well as for infections from other hepatotropic viruses, specifically Epstein-Barr virus, cytomegalovirus, herpes simplex virus and human immunodeficiency virus, were negative.

ALP, alkaline phosphatase; ALT, alanine aminotransferase; AMA, antimitochondrial antibodies; ANA, antinuclear antibodies; ANCA, antineutrophil cytoplasmic antibodies; ASMA, antismooth muscle antibodies; AST, aspartate aminotransferase;Cre, creatinine; DBL, direct bilirubin; $\gamma-G T$, gamma-glutamyl transferase; LKM, liver-kidney microsome; PLT, platelets; SLA, soluble liver antigen; TBL, total bilirubin; UA, uric acid; WBC, white blood cells.

\section{DISCUSSION}

Differential Diagnosis

Overall, this patient exhibited AKI with pre-renal azotemia, mixed acid-base and electrolyte disorders (see below), and hepatic impairment (acute hepatitis and mild cholestasis). The differential diagnosis was based on these abnormalities.

Traditionally, AKI is classified into pre-renal, renal and post-renal (Table 2). HG, haemorrhage and infections (mainly septic abortion) are the major causes of pre-renal AKI in the first trimester ${ }^{[3]}$. Our patient did not have any abnormal urinalysis findings nor did she take any medications, allowing us to rule out intrinsic renal causes (Table 2). Disorders of the second and third trimesters (Table 3) were not considered possible diagnoses. Therefore, we attributed pre-renal AKI to intense vomiting. 


\begin{tabular}{|l|l|}
\hline Pre-renal & Hyperemesis gravidarum, haemorrhage, heart failure, sepsis \\
\hline Renal & $\begin{array}{c}\text { Thrombotic microangiopathies, HELLP syndrome, AFLP, } \\
\text { preeclampsia/eclampsia, glomerulonephritis, acute tubular or } \\
\text { cortical necrosis, pyelonephritis, acute interstitial nephritis, } \\
\text { amniotic fluid embolism, lupus nephritis, medications }\end{array}$ \\
\hline Postrenal & $\begin{array}{c}\text { Hydronephrosis caused by uterine compression, ureteral } \\
\text { obstruction (e.g., stones, tumour), obstruction at bladder outlet }\end{array}$ \\
\hline
\end{tabular}

Table 2. Causes of acute kidney injury in pregnancy AFLP, acute fatty liver of pregnancy; HELLP, haemolysis, elevated liver enzymes and low platelets.

\begin{tabular}{|c|c|c|c|}
\hline Disease & Pregnancy timeline & $\begin{array}{c}\text { Clinical symptoms and } \\
\text { findings }\end{array}$ & Laboratory findings \\
\hline Hyperemesis gravidarum & First trimester & $\begin{array}{c}\text { Nausea, vomiting, weight loss, } \\
\text { dehydration }\end{array}$ & $\begin{array}{c}\text { Ketonuria, electrolyte and } \\
\text { acid-base disorders, } \\
\uparrow A S T / A L T\end{array}$ \\
\hline Preeclampsia, eclampsia & Second/third trimester & $\begin{array}{l}\text { Hypertension, oedema, } \\
\text { headaches, seizures, coma }\end{array}$ & $\begin{array}{c}\text { Proteinuria, } P L T<100,000, \\
\text { TBL }>1.2 \mathrm{mg} / \mathrm{dl}, \\
\uparrow A S T / A L T\end{array}$ \\
\hline HELLP & Third trimester & $\begin{array}{l}\text { Nausea, vomiting, } \\
\text { abdominal pain, } \\
\text { hypertension, oedema }\end{array}$ & $\begin{array}{c}\text { Proteinuria, } P L T<100,000, \\
\text { TBL>1.2 mg/dl, } \\
\uparrow A S T / A L T\end{array}$ \\
\hline AFLP & Third trimester & $\begin{array}{l}\text { Nausea, vomiting, } \\
\text { abdominal pain, } \\
\text { fatigue, jaundice }\end{array}$ & $\mathrm{TBL}<5 \mathrm{mg} / \mathrm{dl}, \mathrm{AST} / \mathrm{ALT}<1,000$ \\
\hline$I C P$ & Second/third trimester & $\begin{array}{c}\text { Pruritus, abdominal pain, fatigue, } \\
\text { steatorrhoea, } \\
\text { jaundice }\end{array}$ & $\begin{array}{l}\text { TBL }<5 \mathrm{mg} / \mathrm{dl}, \uparrow \text { ALP, } \\
\uparrow \text { cholic acids, } \\
\text { AST/ALT }>1,000 \text { IU/I }\end{array}$ \\
\hline $\begin{array}{c}\text { Viral hepatitis } \\
\text { (HAV, HBV, HCV, HDV, HEV) }\end{array}$ & Any trimester & $\begin{array}{l}\text { Nausea, vomiting, } \\
\text { abdominal pain, fever, } \\
\text { diarrhoea, jaundice, } \\
\text { skin eruptions }\end{array}$ & $\begin{array}{l}\uparrow T B I L, \uparrow A S T / A L T, \\
(+) \text { serological tests }\end{array}$ \\
\hline $\begin{array}{l}\text { Hepatotropic viruses } \\
\text { (CMV, EBV, HSV, HIV) }\end{array}$ & Any trimester & $\begin{array}{c}\text { Nausea, vomiting, } \\
\text { abdominal pain, fever, diarrhoea, } \\
\text { jaundice, } \\
\text { skin eruptions, fatigue, } \\
\text { sore throat }\end{array}$ & $\begin{array}{c}\uparrow A S T / A L T, \\
\text { lymphocytosis or lymphopenia } \\
(+) \text { serological tests }\end{array}$ \\
\hline Autoimmune hepatitis & Any trimester & $\begin{array}{l}\text { General non-specific symptoms, } \\
\text { jaundice, findings suggestive of } \\
\text { cirrhosis in long-standing disease }\end{array}$ & $\begin{array}{c}\uparrow T B I L, \uparrow \text { AST/ALT, } \\
\text { (+) ANA, ASMA, anti-LKM, } \\
\text { anti-SLA }\end{array}$ \\
\hline Primary biliary cholangitis & Any trimester & $\begin{array}{l}\text { Jaundice, pruritus, } \\
\text { xanthomas, xanthelasmas }\end{array}$ & $\begin{array}{c}\uparrow T \text { TBIL, } \\
\text { (+) ANA, AMA, hyperlipidemio }\end{array}$ \\
\hline Primary sclerosing cholangitis & Any trimester & $\begin{array}{c}\text { Jaundice, pruritus, } \\
\text { symptoms of ulcerative colitis }\end{array}$ & $\begin{array}{c}\uparrow T B I L, \uparrow A L P, \uparrow \gamma-G T, \\
(+) \text { ANA, ANCA }\end{array}$ \\
\hline Wilson disease & Any trimester & $\begin{array}{c}\text { Jaundice, acute hepatitis, } \\
\text { acute liver failure, } \\
\text { neurological disorders, psychosis }\end{array}$ & $\begin{array}{c}\uparrow \text { TBIL, } \uparrow \text { AST/ALT, } \\
\uparrow \text { urine copper, } \\
\downarrow \text { ceruloplasmin, } \\
\text { Coombs }(-) \text { aemolytic anaemia }\end{array}$ \\
\hline
\end{tabular}

Table 3. Liver disease in pregnancy

AFLP, acute fatty liver of pregnancy; ALP, alkaline phosphatase; ALT, alanine aminotransferase; AMA, antimitochondrial antibodies; ANA, antinuclear antibodies; ANCA, antineutrophil cytoplasmic antibodies; ASMA, anti-smooth muscle antibodies; AST, aspartate aminotransferase; CMV, cytomegalovirus; EBV, Epstein-Barrvirus; $\gamma$-GT,gamma-glutamyl transferase; HAV, hepatitis A virus; HBV, hepatitis B virus; HCV, hepatitis C virus; HDV, hepatitis D virus; HELLP, haemolysis, elevated liver enzymes and low platelets; HEV, hepatitis E virus; HIV, human immunodeficiency virus; HSV, herpes simplex virus; ICP, intra hepatic cholestasis of pregnancy; LKM, liver-kidney microsomal; PLT, platelets; TBL, total bilirubin; SLA, soluble liver antigen. 
Our patient also had acute hepatitis and mild cholestasis. The differential diagnosis of liver disease in pregnancy includes several disorders which either develop during pregnancy or occur incidentally in pregnancy (Table 3). With the exception of HG, the other pregnancy-related disorders do not occur in the first trimester and so were excluded. Cholestatic liver disease, autoimmune hepatitis, Wilson disease and viral hepatitis were also considered; therefore, specific laboratory exams and an ultrasound of the abdomen were performed.

Serological tests for viral hepatitis and infections from other hepatotropic viruses were negative (Table 1). All tested autoantibodies were also negative (Table 1), allowing us to exclude, with nearly total certainty, autoimmune hepatitis, primary biliary cholangitis and primary sclerosing cholangitis out of autoimmune liver diseases.

Ceruloplasmin levels were within normal limits, while the patient's clinical picture was not suggestive of Wilson disease. Furthermore, the levels of alkaline phosphatase are usually not elevated in this disease ${ }^{[3]}$. Finally, ultrasound of the abdomen revealed no abnormal findings, and therefore, cholelithiasis, choledocholithiasis, pancreatitis and Budd-Chiari syndrome were unlikely. Thus, we attributed hepatic impairment to HG. Usually transaminases are mildly increased and rise up to approximately $200 \mathrm{U} / \mathrm{I}^{[4]}$. The first study to report transaminases as high as $1,000 \mathrm{U} / \mathrm{I}$ was a small prospective study $(\mathrm{N}=12)$ where transaminase elevation occurred in $50 \%$ of patients with $\mathrm{HG}{ }^{[5]}$. Furthermore, there is a case of a 30-year-old prima gravida at 14 weeks of gestation with HG and abnormal liver tests, including an alanine aminotransferase (ALT) of $1,065 \mathrm{IU} / \mathrm{I}^{[5]}$. Contrary to our case, there no AKI was reported in the aforementioned studies.

Regarding AKI in HG, only one case report has described such severe pre-renal azotemia, which was in a 21-year-old woman at week 15 of gestation with serum creatinine $10.7 \mathrm{mg} / \mathrm{dl}$ and urea $171 \mathrm{mg} / \mathrm{dl}{ }^{[5]}$. This patient underwent daily haemodialysis for 5 days with subsequent recovery of renal function. In our case, the recurrent and long-lasting vomiting caused extreme volume contraction resulting in $\mathrm{AKI}$, severe metabolic alkalosis, hyponatremia, hypokalemia and hyperuricemia. The extremely elevated transaminase levels were also attributed to the patient's hypovolemic state in the context of ischaemic hepatitis.

The impressive correction of the patient's clinical condition and laboratory abnormalities after fluid replacement (see below) also imply that HG was the culprit for all observed disorders.

\section{Treatment}

Appropriate fluid administration to correct both acid-base and electrolyte disorders as well as volume depletion was the treatment of choice. AKI and ischaemic hepatitis resolved with restoration of volume depletion. We used an isotonic solution containing potassium in order to restore both volume and potassium deficits. The patient was closely monitored, mainly to avoid overcorrection of hyponatremia. Hyponatremia was corrected over 3 days. By then, the patient had regained full consciousness and was discharged on the 7th day with normal renal function, electrolyte and blood gas values and only slightly increased liver enzyme levels (Table 1). Unfortunately, she decided to discontinue the pregnancy as she was afraid of the consequences of the metabolic abnormalities for the fetus.

\section{CONCLUSION}

The diagnosis of HG may be challenging and HG may become a life-threatening condition both for the mother and the fetus if serious metabolic abnormalities occur. The ensuing unfavourable consequences can be overcome with suitable treatment.

\section{REFERENCES}

1. Erick M, Cox JT, Mogensen KM.ACOG Practice Bulletin No. 189: nausea and vomiting of pregnancy. Obstet Gynecol 2018;131(5):935.

2. London V, Grube S, Sherer DM, Abulafia O.Hyperemesis gravidarum: a review of recent literature. Pharmacology 2017;100(3-4):161-171.

3. Korman JD, Volenberg I, Balko J, Webster J, Schiodt FV, Squires RH, et al.Screening for Wilson disease in acute liver failure: a comparison of currently available diagnostic tests. Hepatology 2008;48(4):1167-1174.

4. Lee NM, Brady CW. Liver disease in pregnancy. World J Gastroenterol 2009;15(8):897-906.

5. Conchillo JM, Koek GH. Hyperemesis gravidarum and severe liver enzyme elevation. J Hepatol 2002;37(1):162-163. 